Article

\title{
An Improved Approach for Practical Synthesis of 5-Hydroxymethyl-2'-deoxycytidine (5hmdC) Phosphoramidite and Triphosphate
}

\author{
Dong-Zhao Yang ${ }^{1}$, Zhen-Zhen Chen ${ }^{1}$, Mei Chi ${ }^{1}$, Ying-Ying Dong ${ }^{1}$, Shou-Zhi Pu ${ }^{1,2, *}$ and Qi Sun ${ }^{1, *(1)}$ \\ 1 Jiangxi Key Laboratory of Organic Chemistry, Jiangxi Science and Technology Normal University, \\ Nanchang 330013, China; yangdongzhao1@126.com (D.-Z.Y.); chenzhenzhen5@126.com (Z.-Z.C.); \\ chimei5@126.com (M.C.); dongyingying0@126.com (Y.-Y.D.) \\ 2 Department of Ecology and Environment, Yuzhang Normal University, Nanchang 330103, China \\ * Correspondence: pushouzhi@tsinghua.org.cn (S.-Z.P.); sunqi@jxstnu.edu.cn (Q.S.)
}

Citation: Yang, D.-Z.; Chen, Z.-Z.; Chi, M.; Dong, Y.-Y.; Pu, S.-Z.; Sun, Q. An Improved Approach for Practical Synthesis of 5-Hydroxymethyl-

2 '-deoxycytidine (5hmdC)

Phosphoramidite and Triphosphate. Molecules 2022, 27, 749. https:// doi.org/10.3390/molecules27030749

Academic Editor: Brenno A.D. Neto

Received: 6 January 2022

Accepted: 20 January 2022

Published: 24 January 2022

Publisher's Note: MDPI stays neutral with regard to jurisdictional claims in published maps and institutional affiliations.

Copyright: (C) 2022 by the authors. Licensee MDPI, Basel, Switzerland. This article is an open access article distributed under the terms and conditions of the Creative Commons Attribution (CC BY) license (https:// creativecommons.org/licenses/by/ $4.0 /)$.

\begin{abstract}
Hydroxymethyl-2'-deoxycytidine (5hmdC) phosphoramidite and triphosphate are important building blocks in 5hmdC-containing DNA synthesis for epigenetic studies. However, efficient and practical methods for the synthesis of these compounds are still limited. The current research provides an intensively improved synthetic method that enables the preparation of commercially available cyanoethyl-protected 5hmdC phosphoramidite with an overall yield of $39 \%$ on $5 \mathrm{~g}$ scale. On the basis of facile and efficient accesses to cyanoethyl protected-5hmdU and 5hmdC intermediates, two efficient synthetic routes for $5 \mathrm{hmdC}$ triphosphate were also developed.
\end{abstract}

Keywords: 5-hydroxymethyl-2'-deoxycytidine (5hmdC); cyanoethyl ether; phosphoramidite; triphosphate; $\mathrm{P}(\mathrm{V})-\mathrm{N}$ activation

\section{Introduction}

5-Hydroxymethyl-2'-deoxycytidine (5hmdC) is a key oxidative intermediate in the demethylation pathway of 5-methyl-2'-deoxycytidine ( $5 \mathrm{mdC}$ ) mediated by ten-eleven translocation (TET) proteins in epigenetic regulation [1-7]. More recently, $5 \mathrm{hmdC}$ has also been found to play pivotal roles in many crucial physiological processes, such as embryonic development [8], neurodevelopment [9-11], cellular differentiation [12], and initiation/progression of cancer [13,14]. However, it is believed that more biological functions of $5 \mathrm{hmdC}$ are still waiting to be unraveled [15,16]. To this end, synthesis of 5hmdC-containing oligodeoxynucleotides (ODNs) has been employed as an essential tool. Other than conventional phosphoramidite-based DNA synthesis with protected $5 \mathrm{hmdC}$ phosphoramidite as the building block $[17,18]$, polymerase chain reaction (PCR) has also been utilized as an alternative approach to incorporate $5 \mathrm{hmdC}$ into DNA fragments by using $5 \mathrm{hmdC}$ triphosphate as the substrate $[19,20]$.

As shown in Figure 1A, five different types of $5 \mathrm{hmdC}$ phosphoramidite building blocks have been reported to date. 2-Cyanoethyl (1) is the first protecting group utilized for $5-\mathrm{CH}_{2} \mathrm{OH}$ of $5 \mathrm{hmdC}$ [21]. Afterwards, acetyl (2) [22], cyclic carbamate (3) [23], and $t$-butyldimethylsilyl (4) [24] have also been employed as protecting groups. More recently, 2-nitrobenzyl-protected 5hmdC phosphoramidite (5) has enabled photocaged epigenetic labeling of DNA fragments at specific positions [25]. Currently, cyanoethyl-protected 5hmdC phosphoramidite (1) is most widely used for automated DNA synthesis and available from commercial suppliers. Though the final cleavage of cyanoethyl ether requires elongated reaction time and elevated temperature, however, its excellent stability during DNA synthesis, compatibility with existing DNA synthetic protocols, and clean deprotection are its advantages over other competitors. 
(A)
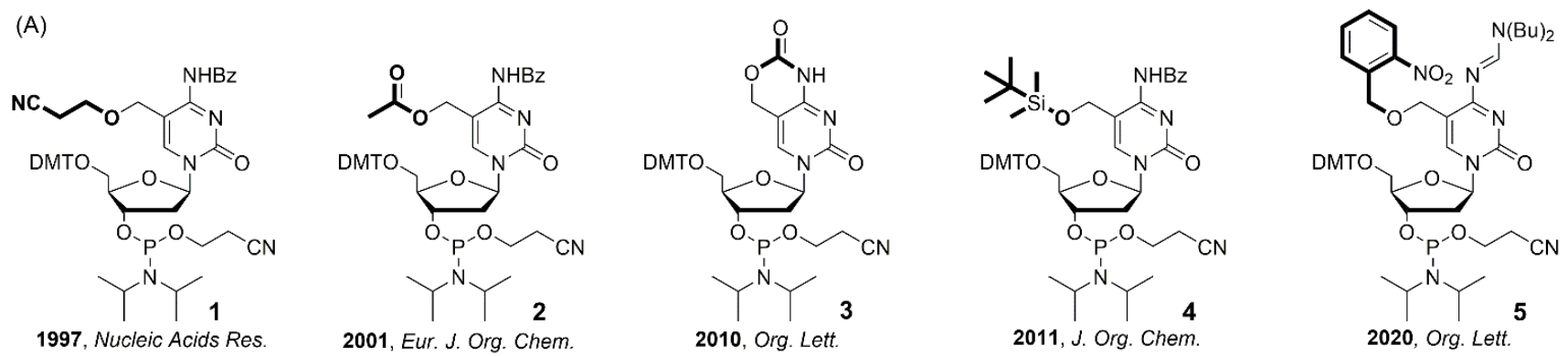

(B)

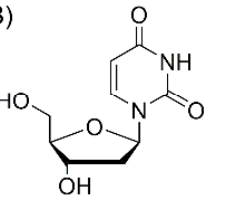

2001, Eur. J. Org. Chem.

2010, Org. Lett

Method A (MA):

$24 \%$ overall yield

$37 \%$ aq $\mathrm{HCHO}$

$\mathrm{KOH}, 65^{\circ} \mathrm{C}, 6 \mathrm{~d}$

2011, Bioorg. Med. Chem. Lett.

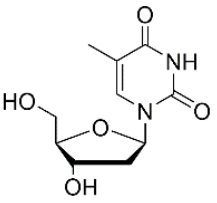

2015, Bioorg. Med. Chem Lett.

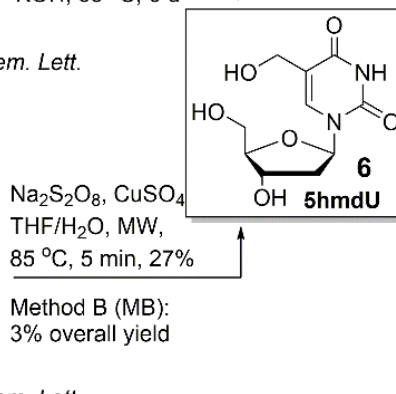

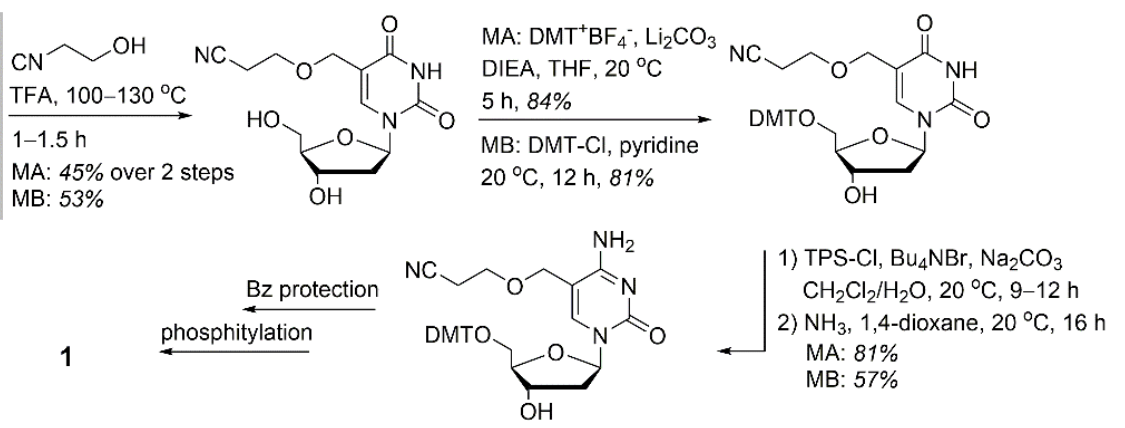

Figure 1. 5hmdC Phosphoramidites with different protecting groups (A) and two improved synthetic methods for 5 hmdC phosphoramidite $\mathbf{1}$ (B).

In 2011 and 2015, Schofield [26] and Shao [27] reported two improved methods for the synthesis of cyanoethyl-protected $5 \mathrm{hmdC}$ phosphoramidite (1) starting from 2'deoxyuridine $(\mathrm{dU})$ and thymidine $(\mathrm{dT})$, respectively (Figure $1 \mathrm{~B})$. Other than the classic benzoyl (Bz) protection and phosphitylation steps, most of key steps including the initial conversion to 5-hydroxymethyl-2'-deoxyuridine (5hmdU), cyanoethyl protection, DMT protection, and $C^{4}$-amination steps still suffer from either low-yielding or slow reaction rate. While Schofield's route (Method A) gave 1 in $24 \%$ overall yield, Shao's approach (Method B) afforded $\mathbf{1}$ in only 3\% overall yield. Herein, we report an intensively optimized method for practical synthesis of $\mathbf{1}$ with an overall yield of $39 \%$ on $5 \mathrm{~g}$ scale. Moreover, two synthetic routes based on cyanoethyl protected-5hmdU and $5 \mathrm{hmdC}$ intermediates were also developed to access $5 \mathrm{hmdC}$ triphosphate on $50 \mathrm{mg}$ scale.

\section{Results and Discussion}

\subsection{Synthesis of Cyanoethyl-Protected 5hmdC Phosphoramidite (1)}

As illustrated in Scheme 1, our method employed inexpensive dT starting material, which was first converted to diTBS-protected dT (7) in 96\% yield and purified via simple precipitation. After free radical bromination at 5-methyl position, 5-bromomethyl dU (5BrmdU) intermediate (8) was concentrated and directly treated with 2-cyanoethanol at ambient temperature for $15 \mathrm{~min}$ to afford cyanoethyl-protected $5 \mathrm{hmdU}$ (9) in 78\% yield. Treating 9 with DMT tetrafluoroborate $\left(\mathrm{DMT}^{+} \mathrm{BF}_{4}{ }^{-}\right)$in pyridine resulted in fast and efficient introduction of DMT to the sterically hindered $5^{\prime}-\mathrm{OH}(85 \%, 10)$. According to the new $C^{4}$-amination method we developed, instant activation with PyAOP (1 min, 11) followed by aminolysis with conc. ammonia $(4 \mathrm{~h})$ yielded $5 \mathrm{hmdC}$ intermediate (12) in $84 \%$ yield. N-Benzoylation of $\mathbf{1 2}$ with benzoic anhydride in DMF at $70{ }^{\circ} \mathrm{C}$ greatly shortened reaction time of $\mathbf{1 3}$ from 2-4 days (at ambient temperature) [26] to only $2 \mathrm{~h}$ without adverse effects on either yield or chemoselectivity. Finally, phosphitylation with 2-cyanoethyl $\mathrm{N}, \mathrm{N}$ diisopropylchlorophosphoramidite in the present of triethylamine afforded the desired 
cyanoethyl-protected 5hmdC (1) in 83\% yield. Compared to Schofield's and Shao's methods, the current approach achieved $39 \%$ overall yield in $5 \mathrm{~g}$ scale practical synthesis.

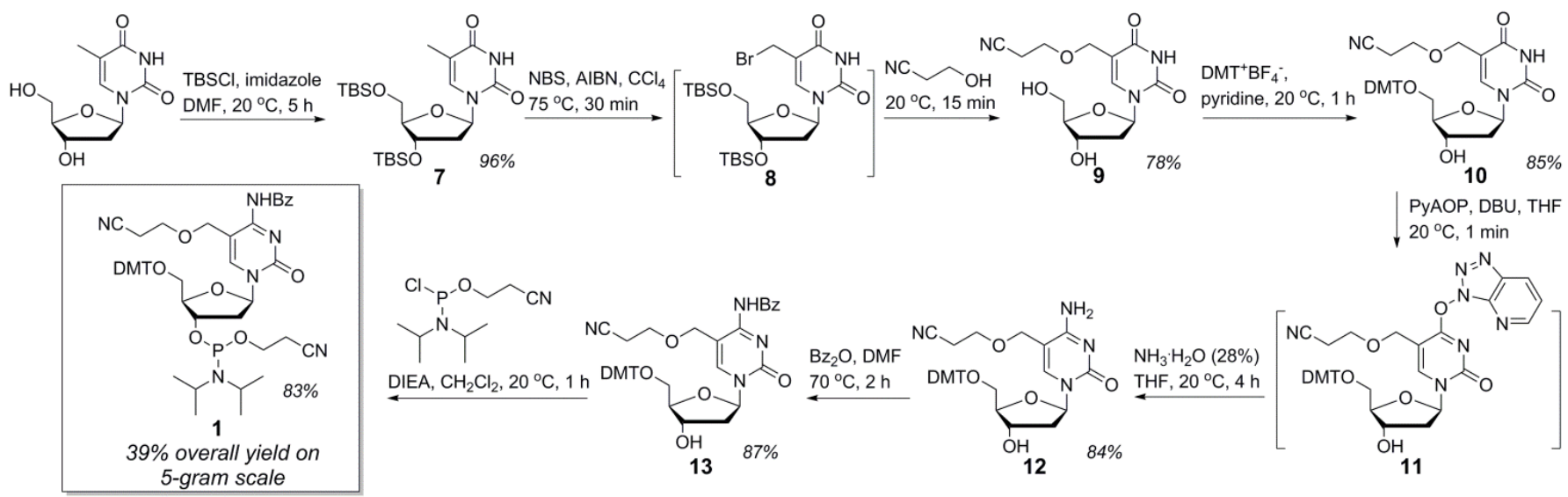

Scheme 1. An improved method for practical synthesis of cyanoethyl-protected 5hmdC phosphoramidite (1).

Originally, we found that 5hmdU (6) could be efficiently obtained by hydrolyzing $5 \mathrm{BrmdU}(8)$ with TFA $/ \mathrm{H}_{2} \mathrm{O}(10: 1, v / v)$ in $71 \%$ yield. However, the following synthesis of cyanoethyl ether in the presence of TFA at $100{ }^{\circ} \mathrm{C}$ according to the previous reports $[26,27]$ yielded the desired 9 in only 51\% yield. Therefore, we abandoned the synthesis of $5 \mathrm{hmdU}$ and subsequent condensation with cyanoethanol under harsh conditions. Instead, we attempted to convert 8 directly to cyanoethyl ether $\mathbf{9}$ via alcoholysis with cyanoethanol under mild conditions. The simultaneous alcoholysis and cleavage of TBS by HBr generated in situ only took $15 \mathrm{~min}$ at ambient temperature, and column purification afforded 9 in $78 \%$ yield (Scheme 2).

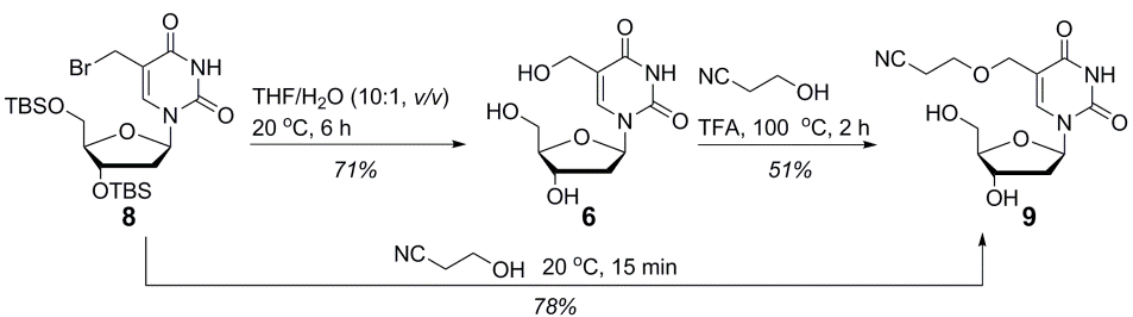

Scheme 2. One-step synthesis of cyanoethyl-protected 5hmdU (9) from diTBS-protected 5BrhmdU (8).

In the following tritylation of 5'-OH with DMT-Cl in pyridine, we encountered the same incomplete reaction and low yielding scenario $(51 \%, 12 \mathrm{~h})$ mentioned by Schofield and coworkers [26] due to the elevated steric hindrance resulting from cyanoethyl protecting group. To solve this problem, we increased the reaction temperature to 40 and $60{ }^{\circ} \mathrm{C}$ (Table 1 , Entry 1-3). However, the yield of $\mathbf{1 0}$ dropped ever lower due to the formation of more diDMT-protected side product. In addition, we also tested the reactions with a catalytic amount of DMAP, 2 equiv of DIPEA, and a new tritylation reagent, DMT-trifluoroacetate (Table 1, Entry 4-7) [28]. However, none of these conditions led to improved results. Surprisingly, when $\mathrm{DMT}^{+} \mathrm{BF}_{4}{ }^{-}$along with additives was applied according to Schofield's method, the yield of $\mathbf{1 0}$ was still very low (Table 1, Entry 8) [26]. Fortunately, our further optimization found that $\mathrm{DMT}^{+} \mathrm{BF}_{4}-$ alone in pyridine (without any additives) could afford the desired $5^{\prime}-O$ tritylated product 10 in $85 \%$ yield within only $1 \mathrm{~h}$. A possible mechanistic explanation for this result is because pyridine favors the dissociation of $\mathrm{DMT}^{+} \mathrm{BF}_{4}{ }^{-}$into ionic form. Compared to the covalently linked DMT-Cl, $\mathrm{DMT}^{+}$cation is more flattened and, therefore, much easier accessible to the $5^{\prime}-\mathrm{OH}$ of 9 . 
Table 1. Optimization of tritylation conditions for synthesis of $\mathbf{1 0 .}$

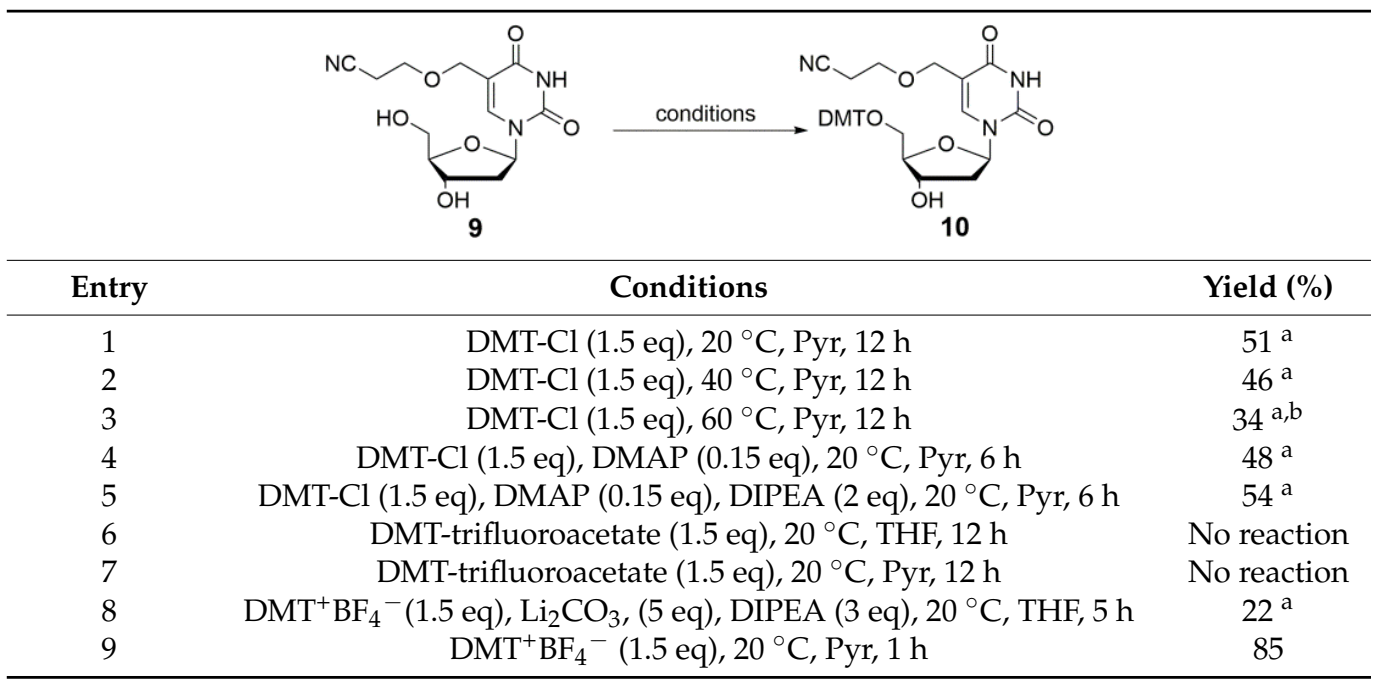

a 9 was not completely consumed when the reaction stopped. ${ }^{\mathrm{b}}$ diDMT-protected product formed.

The last bottle neck of the reported synthetic routes is the conversion of $\mathbf{1 0}$ to its $\mathrm{dC}$ counterpart 12. The reported reaction yields based on 2,4,6-triisopropylbenzenesulfonyl chloride (TPS-Cl) activating reagent showed a large discrepancy (MA: $81 \%$ vs MB: $58 \%$ ). In addition, both the biphasic activation and aminolysis steps were quite slow. In our hands, incomplete activation of urosine was observed and the yield of $\mathbf{1 1}(53 \%)$ was close to the one reported in Method B. We then tested the new BOP-based method reported by Lakshman and coworkers in 2017 [29]. However, the yield of 12 was still moderate (56\%). To solve this problem, we systematically investigated the reactivity of different types of onium salt coupling reagents on the $\mathrm{C}^{4}$ amination and found that PyAOP is much more advantageous in both activation and aminolysis steps than BOP, especially in the case of structurally more hindered pyrimidine substrates such as 10. Compared to the TPS-Cl method, the ultrafast activation by PyAOP ( $1 \mathrm{~min})$ followed by aminolysis with concentrated ammonia $(4 \mathrm{~h})$ afforded 12 in $84 \%$ yield (Scheme 3 ). The more detailed condition optimization, mechanistic investigation, and application scope of onium salt-based $C^{4}$-amination method for oxidized $5 \mathrm{mdC}$ derivatives have been described in a previous research article reported by our group [30]. However, it should be noted that, similar to the above mentioned $\mathrm{DMT}^{+} \mathrm{BF}_{4}{ }^{-}, \mathrm{PyAOP}$ is an onium salt coupling reagent. Therefore, the mechanistic rationale for its superb activating reactivity on sterically hindered $\mathbf{1 0}$ may also be ascribed to the significantly lowered steric hindrance of more flattened tripyrrolidinophosphonium ion.

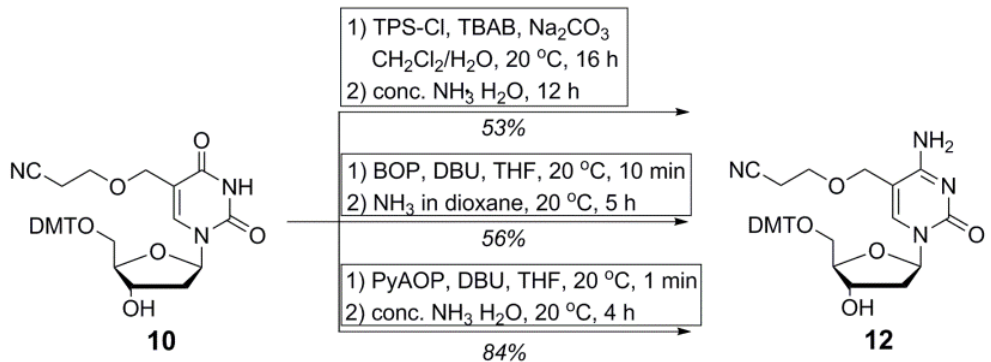

Scheme 3. Comparison of TPS-Cl, BOP, and PyAOP-based amination methods for the synthesis of $\mathbf{1 2}$.

\subsection{Synthesis of 5 hmdC Triphosphate (14)}

As mentioned above, $5 \mathrm{hmdC}$ triphosphate (14) is the key substrate for PCR-based $5 \mathrm{hmdC}$-containing DNA synthesis. Previously, we have reported a synthetic route for 14, starting from acetyl/diTBS-protected $5 \mathrm{hmdC}$ [31]. The current synthetic advances made 
in the preparation of cyanoethyl/DMT-protected 5hmdC phosphoramidite (1) offered an excellent opportunity to gain more efficient accesses to $\mathbf{1 4}$.

In the first synthetic route (Scheme 4), we started with cyanoethyl-protected 5hmdU (9). Activation by PyAOP ( $1 \mathrm{~min})$ followed by aminolysis with concentrated ammonia $(4 \mathrm{~h})$ yielded cyanoethyl-protected $5 \mathrm{hmdC}(15)$ in $80 \%$ yield. However, regioselective phosphorylation at $5^{\prime}-$ $\mathrm{OH}$ position gave cyanoethyl-protected $5 \mathrm{hmdC}$ monophosphate (16) in only $45 \%$ yield possibly due to the increased steric hindrance resulting from the cyanoethyl ether. Redox condensation with $\mathrm{PPh}_{3}, 2$-aminophenyl disulfide, and piperidine smoothly mediated the conversion to phosphoropiperidate 17 (6h, 88\%) [32]. The coupling of $\mathbf{1 7}$ and pyrophosphate was conducted with 4,5-dicyanoimidazole (DCI) via the P(V)-N activation method. Then, the cyanoethyl protecting group was removed by treating the triphosphate with concentrated ammonia at $40^{\circ} \mathrm{C}$ for $12 \mathrm{~h}$. As has been reported [21,26], we found that concentrated ammonia can barely cleave cyanoethyl ether at ambient temperature. However, for small molecular substrates such as 14 , moderately elevated temperature $\left(40^{\circ} \mathrm{C}\right)$ is enough for its deprotection. The high temperature $\left(75^{\circ} \mathrm{C}\right)$ required in DNA synthesis is not necessary and impractical for triphosphate synthesis. Finally, purification by ion-exchange chromatography afforded the desired $5 \mathrm{hmdC}$ triphosphate (14) in $72 \%$ yield over two steps on $50 \mathrm{mg}$ scale. Compared to our previous method based on Ac-protected $5 \mathrm{hmdC}$ intermediate (8 steps from diTBS-dT and $15 \%$ overall yield), the new route afforded 14 in $18 \%$ over 5 steps.
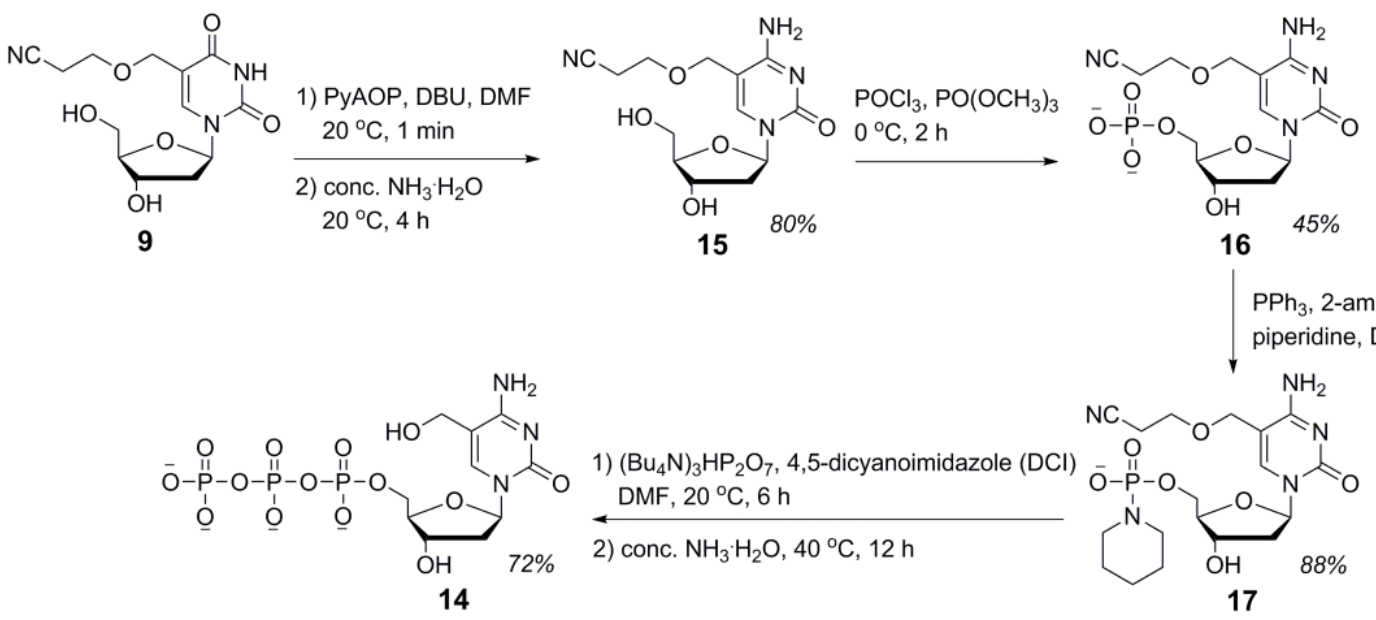

Scheme 4. Cyanoethyl-protected 5hmdU (9)-based synthetic route for 14.

Due to the low-yielding monophosphorylation step in the first route, we chose to start with DMT/cyanoethyl-protected 5hmdC (12) in the second route and synthesize 14 via fully protected $5 \mathrm{hmdC}$ phosphoropiperidate intermediate (20) [33]. First, the 3'$\mathrm{OH}$ and $4-\mathrm{NH}_{2}$ of $\mathbf{1 4}$ were protected by benzyloxycarbonyl $(\mathrm{Cbz})$ groups in $84 \%$ yield. After the DMT group was removed by TFA $(90 \%, 19), 5^{\prime}-\mathrm{OH}$ was phosphitylated with 2benzyl $N, N$-diisopropylchlorophosphoramidite. In situ hydrolysis and oxidative coupling with piperidine yielded the fully protected phosphoropiperidate 20 in $79 \%$ yield over three consecutive steps. After $\mathrm{Cbz}$ and $\mathrm{Bn}$ protecting groups were removed by catalytic hydrogenation, the deprotected phosphoropiperidate 17 was treated with pyrophosphate in the presence of DCI as the promotor. The highly efficient $\mathrm{P}(\mathrm{V})-\mathrm{N}$ activation method afforded the triphosphate in over $95 \%$ conversion as determined by ${ }^{31} \mathrm{P}$ NMR. Finally, cleavage of cyanoethyl ether with concentrated ammonia at $40{ }^{\circ} \mathrm{C}$ followed by routine ion-exchange chromatography gave $\mathbf{1 4}$ in $73 \%$ yield over three consecutive steps on $50 \mathrm{mg}$ scale (Scheme 5). Compared to the first synthetic route based on $\mathbf{9}$, the second route based on 20 afforded 14 in a higher overall yield ( $24 \%$ ) but required two extra steps (total 7 steps from diTBS-dT). 


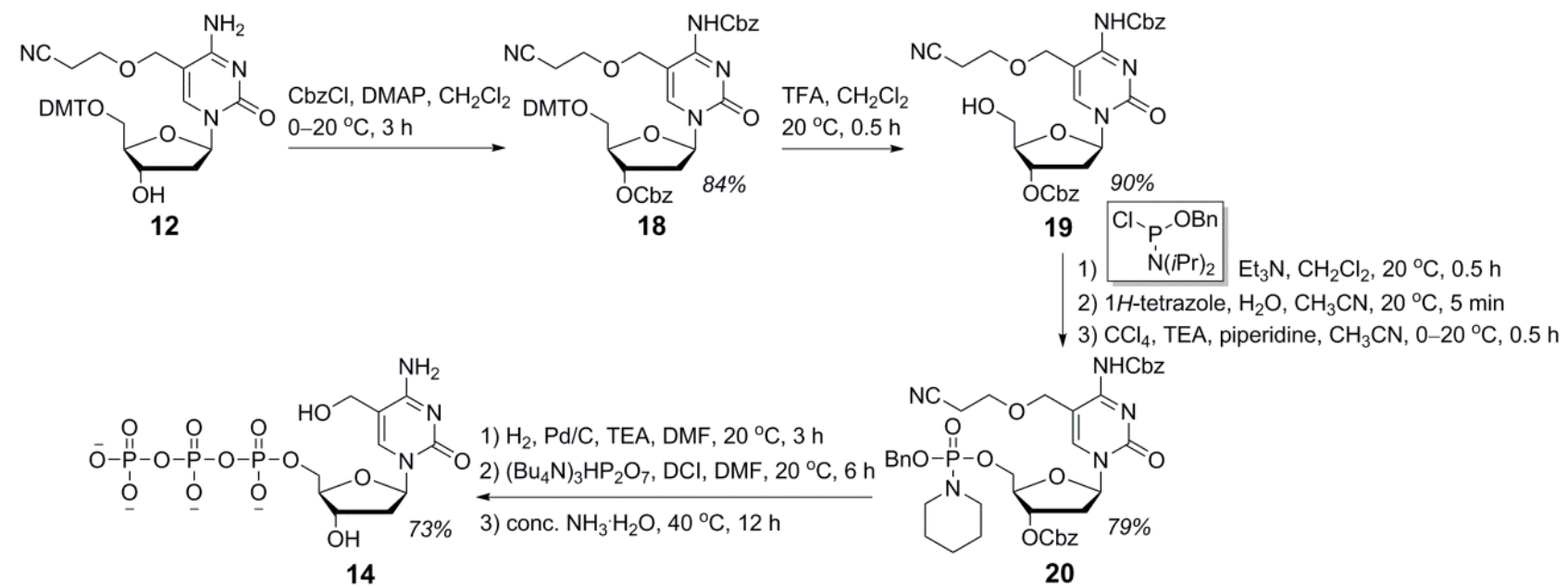

Scheme 5. Fully protected phosphoropiperidate (20)-based synthetic route for 14 .

\section{Materials and Methods}

\subsection{General Methods}

Chemical reagents and solvents were purchased from Leyan-Shanghai Haohong Scientific Co. Ltd., Shanghai, China. Reactions were monitored by TLC plates coated with $0.25 \mathrm{~mm}$ silica gel $60 \mathrm{~F}_{254}$ and visualized by UV irradiation ( $254 \mathrm{~nm}$ ). Flash column chromatography employed silica gel (particle size 32-63 $\mu \mathrm{m}$, Qingdao Haiyang Chemicals, Qingdao, China). NMR spectra were acquired on an AV-400 instrument (Bruker BioSpin, Faellanden, Switzerland) with chemical shifts reported in ppm and referenced to $\mathrm{CDCl}_{3}$, DMSO- $d_{6}$, or $\mathrm{D}_{2} \mathrm{O}$. IR spectra were obtained with a Vertex-70 instrument (Bruker Optics, Billerica, MA, USA). High-resolution mass spectra were obtained with a Dalton micrOTOFQ II spectrometer (Bruker Optics, Billerica, MA, USA) and reported as $m / z$. Melting points were determined with an X-4 digital melting point apparatus and uncorrected (Tech Instrument, Beijing, China). The characterization data of $\mathbf{1}$ and 9-13 and NMR spectra of all synthesized compounds are provided in the Supplementary Materials.

\subsection{Synthetic Procedures of 5hmdC Phosphoramidite (1) and Intermediates (9-13)}

5-(2-Cyanoethyl)hydroxymethyl-2'-deoxyuridine (9): To a solution of 7 (9.5 g, $20.3 \mathrm{mmol})$ in dry $\mathrm{CCl}_{4}(100 \mathrm{~mL})$ were added NBS $(5.78 \mathrm{~g}, 32.5 \mathrm{mmol})$ and AIBN $(541 \mathrm{mg}, 3.3 \mathrm{mmol})$. The reaction was stirred at $75{ }^{\circ} \mathrm{C}$ for $30 \mathrm{~min}$ until the orange color faded. Upon cooling, the reaction solution was filtered. The filtrate was concentrated in vacuo and dried under high vacuum for $30 \mathrm{~min}$. The crude 8 was dissolved in cyanoethanol $(6.9 \mathrm{~mL}, 101.5 \mathrm{mmol})$ and the reaction was stirred at $20^{\circ} \mathrm{C}$ for $15 \mathrm{~min}$. Then $\mathrm{NaHCO}_{3}(3.4 \mathrm{~g}, 40.6 \mathrm{mmol})$ was added to the solution to adjust $\mathrm{pH}$ to 7. The solution was washed with $\mathrm{CH}_{2} \mathrm{Cl}_{2}(200 \mathrm{~mL} \times 5)$ to remove excess cyanoethanol. Flash column chromatography of the residual syrup $\left(\mathrm{CH}_{2} \mathrm{Cl}_{2} / \mathrm{MeOH}=10: 1\right)$ afforded 9 (4.9 $\mathrm{g}$, $78 \%$ ) as a white solid.

5-(2-Cyanoethyl)hydroxymethyl-5'-(4,4'-dimethoxytrityl)-2'-deoxyuridine (10): To a solution of $9(4.7 \mathrm{~g}, 15.2 \mathrm{mmol})$ in dry pyridine $(60 \mathrm{~mL})$ was added $\mathrm{DMT}^{+} \mathrm{BF}_{4}{ }^{-}(8.9 \mathrm{~g}$, $22.8 \mathrm{mmol}$ ) under argon. The reaction was stirred at $20^{\circ} \mathrm{C}$ for $1 \mathrm{~h}$, then quenched with $\mathrm{MeOH}(5 \mathrm{~mL})$, diluted with $\mathrm{CH}_{2} \mathrm{Cl}_{2}(150 \mathrm{~mL})$, and washed with saturated aq. $\mathrm{NaHCO}_{3}$ solution $(200 \mathrm{~mL} \times 3)$ and $\mathrm{H}_{2} \mathrm{O}(200 \mathrm{~mL})$. The organic layer was dried over anhydrous $\mathrm{Na}_{2} \mathrm{SO}_{4}$ and concentrated in vacuo. Flash column chromatography $\left(\mathrm{CH}_{2} \mathrm{Cl}_{2} / \mathrm{MeOH}=20: 1\right)$ afforded $10(7.9 \mathrm{~g}, 85 \%)$ as a white solid.

5-(2-Cyanoethyl)hydroxymethyl-5'-(4,4'-dimethoxytrityl)-2'-deoxycytidine (12): To a solution of $10(7.3 \mathrm{~g}, 11.9 \mathrm{mmol})$ and PyAOP $(12.4 \mathrm{~g}, 23.8 \mathrm{mmol})$ in dry THF $(60 \mathrm{~mL})$ was added DBU $(3.55 \mathrm{~mL}, 23.8 \mathrm{mmol})$ under argon at $0{ }^{\circ} \mathrm{C}$. The reaction was stirred at $20{ }^{\circ} \mathrm{C}$ for $1 \mathrm{~min}$ and then concentrated $\mathrm{NH}_{3} \cdot \mathrm{H}_{2} \mathrm{O}(28 \mathrm{w} \%, 7.2 \mathrm{~mL}, 95.2 \mathrm{mmol})$ was added. The reaction 
was stirred at $20^{\circ} \mathrm{C}$ for $4 \mathrm{~h}$ and concentrated in vacuo. Flash column chromatography $(\mathrm{DCM} / \mathrm{MeOH}=10: 1)$ afforded $12(6.1 \mathrm{~g}, 84 \%)$ as a white solid.

$N^{4}$-Benzoyl-5-(2-cyanoethyl)hydroxymethyl-5'-(4,4'-dimethoxytrityl)-2' -deoxycytidine (13): To a solution of $\mathbf{1 2}(6.0 \mathrm{~g}, 9.8 \mathrm{mmol})$ in dry THF $(50 \mathrm{~mL})$ was added benzoic anhydride ( $3.3 \mathrm{~g}, 14.7 \mathrm{mmol}$ ) under argon. The reaction was stirred at $70{ }^{\circ} \mathrm{C}$ for $2 \mathrm{~h}$. Upon cooling, the reaction mixture was diluted with $\mathrm{CH}_{2} \mathrm{Cl}_{2}(150 \mathrm{~mL})$. The solution was washed with saturated aq. $\mathrm{NaHCO}_{3}$ solution $(200 \mathrm{~mL}), \mathrm{H}_{2} \mathrm{O}(200 \mathrm{~mL} \times 3)$. The combined organic layer was dried over anhydrous $\mathrm{Na}_{2} \mathrm{SO}_{4}$ and concentrated in vacuo. Flash column chromatography (PE/EA = 1:1) afforded $13(6.1 \mathrm{~g}, 87 \%)$ as a white solid.

$N^{4}$-Benzoyl-5-(2-cyanoethyl)hydroxymethyl-5'-(4,4'-dimethoxytrityl)-2'-deoxycytidine-3'[ $N, N$-diisopropyl- $N$-cyanoethyl]phosphoramidite (1): To a solution of $\mathbf{1 3}(5.0 \mathrm{~g}, 7.0 \mathrm{mmol})$ in dry $\mathrm{CH}_{2} \mathrm{Cl}_{2}(50 \mathrm{~mL})$ were added $\mathrm{N}, \mathrm{N}$-diisopropylethylamine $(3.6 \mathrm{~mL}, 20.9 \mathrm{mmol}$ ) and 2-cyanoethyl $\mathrm{N}, \mathrm{N}$-diisopropylchlorophosphoramidite $(3.1 \mathrm{~mL}, 14.0 \mathrm{mmol})$ under argon. The reaction was stirred at $20^{\circ} \mathrm{C}$ for $1 \mathrm{~h}$ and then aq. $\mathrm{NaHCO}_{3}$ solution $(5 \mathrm{w} \%, 100 \mathrm{~mL})$ was added. The reaction mixture was extracted with $\mathrm{CH}_{2} \mathrm{Cl}_{2}(100 \mathrm{~mL} \times 3)$. The organic layer was dried over anhydrous $\mathrm{Na}_{2} \mathrm{SO}_{4}$ and concentrated in vacuo. Flash column chromatography (PE/EA = 1:1, 0.5\% TEA) afforded $\mathbf{1}(5.3 \mathrm{~g}, 83 \%)$ as a white solid.

\subsection{Synthetic Procedures and Characterization Data of 5hmdC Triphosphate (14) and Intermediates (15-20)}

3-((4-Amino-1-((2R,4S,5R)-4-hydroxy-5-(hydroxymethyl)tetrahydrofuran-2-yl)-2-oxo1,2-dihydropyrimidin-5-yl)methoxy)propanenitrile (15): To a solution of 9 (930 mg, $3 \mathrm{mmol}$ ) in dry DMF $(10 \mathrm{~mL})$ was added PyAOP $(2.5 \mathrm{~g}, 4.8 \mathrm{mmol})$ and DBU $(730 \mathrm{mg}, 4.8 \mathrm{mmol})$. The reaction was stirred at $20^{\circ} \mathrm{C}$ for $1 \mathrm{~min}$ and then concentrated $\mathrm{NH}_{3} \cdot \mathrm{H}_{2} \mathrm{O}(28 \mathrm{w} \%, 460 \mu \mathrm{L}$, $12 \mathrm{mmol}$ ) was added. The reaction was stirred at $20^{\circ} \mathrm{C}$ for $4 \mathrm{~h}$ and then concentrated in vacuo. Flash column chromatography $\left(\mathrm{CH}_{2} \mathrm{Cl}_{2} / \mathrm{MeOH}=8: 1\right)$ afforded $15(746 \mathrm{mg}, 80 \%)$ as a white solid; mp 176-177 ${ }^{\circ} \mathrm{C} .{ }^{1} \mathrm{H}$ NMR $\left(400 \mathrm{MHz}, \mathrm{D}_{2} \mathrm{O}\right): \delta 7.93(\mathrm{~s}, 1 \mathrm{H}), 6.16(\mathrm{t}, J=6.4 \mathrm{~Hz}$, $1 \mathrm{H}), 4.40-4.36(\mathrm{~m}, 3 \mathrm{H}), 4.04-3.96(\mathrm{~m}, 1 \mathrm{H}), 3.85-3.77(\mathrm{~m}, 1 \mathrm{H}), 3.76-3.72(\mathrm{~m}, 1 \mathrm{H}), 3.71-3.66(\mathrm{~m}$, $2 \mathrm{H}), 2.75(\mathrm{t}, J=5.9 \mathrm{~Hz}, 2 \mathrm{H}), 2.45-2.36(\mathrm{~m}, 1 \mathrm{H}), 2.28-2.19(\mathrm{~m}, 1 \mathrm{H}) \mathrm{ppm} ;{ }^{13} \mathrm{C} \mathrm{NMR}(100 \mathrm{MHz}$, $\left.\mathrm{D}_{2} \mathrm{O}\right): \delta 164.6,156.6,142.1,120.0,103.5,86.9,86.4,70.4,65.6,64.3,61.2,39.7,18.3$ ppm; IR (KBr): $v_{\max } 3470,2900,2267,1666,1489,1304,1093 \mathrm{~cm}^{-1}$; HRMS (ESI+) $m / z$ calcd for $\mathrm{C}_{13} \mathrm{H}_{18} \mathrm{~N}_{4} \mathrm{O}_{5} \mathrm{Na}[\mathrm{M}+\mathrm{Na}]^{+} 333.1169$; found 333.1170.

$((2 R, 3 S, 5 R)-5$-(4-Amino-5-((2-cyanoethoxy)methyl)-2-oxopyrimidin-1 $(2 H)$-yl)-3hydroxytetrahydrofuran-2-yl)methyl phosphate (16): To a solution of 15 (500 mg, $1.6 \mathrm{mmol}$ ) in dry $\mathrm{PO}\left(\mathrm{OCH}_{3}\right)_{3}(10 \mathrm{~mL})$ was added $\mathrm{POCl}_{3}(489 \mathrm{mg}, 3.2 \mathrm{mmol})$. The reaction was stirred at $0{ }^{\circ} \mathrm{C}$ for $2 \mathrm{~h}$ and concentrated in vacuo. The crude product was dissolved in deionized $\mathrm{H}_{2} \mathrm{O}(2 \mathrm{~mL})$ and loaded on a DEAE Sephadex A-25 ion exchange column $(2.6 \times 20 \mathrm{~cm})$. Elution with $\mathrm{NH}_{4} \mathrm{HCO}_{3}$ buffer (linear gradient 0.1 to $0.5 \mathrm{M}$ ), combination of appropriate fractions, and lyophilization afforded $\mathbf{1 6}(293 \mathrm{mg}, 45 \%)$ in ammonium salt form as a white solid. ${ }^{1} \mathrm{H}$ NMR $\left(400 \mathrm{MHz}, \mathrm{D}_{2} \mathrm{O}\right): \delta 8.05(\mathrm{~s}, 1 \mathrm{H}), 6.26(\mathrm{t}, J=6.6 \mathrm{~Hz}, 1 \mathrm{H}), 4.53-4.47(\mathrm{~m}, 1 \mathrm{H}), 4.46$ $(\mathrm{s}, 2 \mathrm{H}), 4.19-4.13(\mathrm{~m}, 1 \mathrm{H}), 4.11-3.88(\mathrm{~m}, 2 \mathrm{H}), 3.70(\mathrm{t}, J=5.9 \mathrm{~Hz}, 2 \mathrm{H}), 3.15(\mathrm{q}, J=7.3 \mathrm{~Hz}, 1 \mathrm{H})$, $2.74(\mathrm{t}, J=5.8 \mathrm{~Hz}, 2 \mathrm{H}), 2.44-2.35(\mathrm{~m}, 1 \mathrm{H}), 2.29-2.21(\mathrm{~m}, 1 \mathrm{H}) \mathrm{ppm} ;{ }^{13} \mathrm{C}$ NMR $\left(100 \mathrm{MHz}, \mathrm{D}_{2} \mathrm{O}\right)$ : $\delta 164.8,156.7,142.2,120.0,103.8,86.4,86.0,85.9,71.0,66.6,64.6,64.1,46.9,39.9,18.4,8.4$ ppm; ${ }^{31} \mathrm{P}$ NMR (162 MHz, $\left.\mathrm{D}_{2} \mathrm{O}\right): \delta-0.08$ ppm; IR (KBr): $v_{\max } 3345,2982,2854,2260,1694$, $1671,1415,1226,1060,928,852 \mathrm{~cm}^{-1}$; HRMS (ESI-) $m / z$ calcd for $\mathrm{C}_{13} \mathrm{H}_{18} \mathrm{~N}_{4} \mathrm{O}_{8} \mathrm{P}[\mathrm{M}-\mathrm{H}]^{-}$ 389.0868; found 389.0868.

((2R,3S,5R)-5-(4-Amino-5-((2-cyanoethoxy)methyl)-2-oxopyrimidin-1(2H)-yl)-3hydroxytetrahydrofuran-2-yl)methyl piperidin-1-ylphosphonate (17): To a solution of $16(220 \mathrm{mg}, 0.45 \mathrm{mmol}$, triethylammonium form) and piperidine (192 $\mathrm{mg}, 2.25 \mathrm{mmol})$ in DMSO $(4 \mathrm{~mL})$ were added 2-aminophenyl disulfide $(335 \mathrm{mg}, 1.35 \mathrm{mmol})$ and triphenylphosphine $(655 \mathrm{mg}, 2.5 \mathrm{mmol})$. The reaction was stirred at $20^{\circ} \mathrm{C}$ for $8 \mathrm{~h}$. Then, a solution of NaI in acetone $(0.5 \mathrm{M}, 5 \mathrm{~mL})$ was added dropwise. The resulting white precipitated sodium salt was collected by centrifuge. Passage of the solution of the sodium salt in deionized $\mathrm{H}_{2} \mathrm{O}$ through a bed of Dowex 50W-X8 ion exchange resin $\left(\mathrm{Et}_{3} \mathrm{NH}^{+}\right.$form) and lyophilization 
afforded 17 (240 mg, 88\%) in triethylammonium salt form as white hydroscopic foam. ${ }^{1} \mathrm{H}$ NMR $\left(400 \mathrm{MHz}, \mathrm{D}_{2} \mathrm{O}\right): \delta 8.00(\mathrm{~s}, 1 \mathrm{H}), 6.26(\mathrm{t}, J=6.5 \mathrm{~Hz}, 1 \mathrm{H}), 4.54-4.51(\mathrm{~m}, 1 \mathrm{H}), 4.49(\mathrm{~s}, 2 \mathrm{H})$, $4.20-4.15(\mathrm{~m}, 1 \mathrm{H}), 4.02-3.91(\mathrm{~m}, 2 \mathrm{H}), 3.75(\mathrm{t}, J=5.6 \mathrm{~Hz}, 2 \mathrm{H}), 3.18(\mathrm{q}, J=7.2 \mathrm{~Hz}, 9 \mathrm{H}), 2.94-2.88$ $(\mathrm{m}, 4 \mathrm{H}), 2.78(\mathrm{t}, J=5.2 \mathrm{~Hz}, 2 \mathrm{H}), 2.48-2.41(\mathrm{~m}, 1 \mathrm{H}), 2.35-2.23(\mathrm{~m}, 1 \mathrm{H}), 1.46-1.41(\mathrm{~m}, 6 \mathrm{H}), 1.26$ $(\mathrm{t}, J=7.2 \mathrm{~Hz}, 14 \mathrm{H}) \mathrm{ppm} ;{ }^{13} \mathrm{C}$ NMR $\left(100 \mathrm{MHz}, \mathrm{D}_{2} \mathrm{O}\right): \delta 165.2,157.3,141.9,119.9,103.7,86.5$, 86.2, 71.2, 66.8, 64.3, 64.1, 46.8, 45.9, 40.0, 25.8, 24.1, 18.3, 8.3 ppm; ${ }^{31}$ P NMR (162 MHz, $\left.\mathrm{D}_{2} \mathrm{O}\right)$ : $\delta 9.23$ ppm; IR (KBr): $v_{\max } 3458,2262,1670,1562,1420,1333,1126,1058,967,854 \mathrm{~cm}^{-1}$; HRMS (ESI-) $m / z$ calcd for $\mathrm{C}_{18} \mathrm{H}_{27} \mathrm{~N}_{5} \mathrm{O}_{7} \mathrm{P}[\mathrm{M}-\mathrm{H}]^{-} 456.1654$; found 456.1653 .

Benzyl(1-((2R,4S,5R)-4-(((benzyloxy)carbonyl)oxy)-5-((bis(4-methoxyphenyl)(phenyl) methoxy)methyl)tetrahydrofuran-2-yl)-5-((2-cyanoethoxy)methyl)-2-oxo-1,2-dihydropyrimidin4-yl)carbamate (18): To a solution of 12 (500 mg, $0.82 \mathrm{mmol})$ and DMAP (300 $\mathrm{mg}, 2.46 \mathrm{mmol})$ in dry $\mathrm{CH}_{2} \mathrm{Cl}_{2}(8 \mathrm{~mL})$ was added $\mathrm{Cbz}-\mathrm{Cl}(253 \mu \mathrm{L}, 1.80 \mathrm{mmol})$ at $0{ }^{\circ} \mathrm{C}$. The reaction was slowly warmed to ambient temperature, stirred at $20{ }^{\circ} \mathrm{C}$ for $3 \mathrm{~h}$, and concentrated in vacuo. Flash column chromatography (PE/EA = 8:1) afforded 18 (604 mg, 84\%) as a white solid; mp 92-93 ${ }^{\circ} \mathrm{C} .{ }^{1} \mathrm{H}$ NMR $\left(400 \mathrm{MHz}, \mathrm{CDCl}_{3}\right): \delta 12.21(\mathrm{br}, 1 \mathrm{H}), 7.89(\mathrm{~s}, 1 \mathrm{H}), 7.42-7.24(\mathrm{~m}, 19 \mathrm{H})$, 6.86-6.81 (m, 4H), 6.40-6.34 (m, 1H), 5.29-5.24 (m, 1H), $5.19(\mathrm{~s}, 2 \mathrm{H}), 5.14(\mathrm{~s}, 2 \mathrm{H}), 4.20(\mathrm{~s}, 1 \mathrm{H})$, 4.09-4.04 (m, 1H), 3.92-3.87 (m, 1H), $3.79(\mathrm{~s}, 6 \mathrm{H}), 3.57-3.53(\mathrm{~m}, 1 \mathrm{H}), 3.34-3.31(\mathrm{~m}, 1 \mathrm{H}), 3.28$ $(\mathrm{t}, J=6.9 \mathrm{~Hz}, 2 \mathrm{H}), 2.62-2.55(\mathrm{~m}, 1 \mathrm{H}), 2.43-2.34(\mathrm{~m}, 1 \mathrm{H}), 1.96(\mathrm{t}, J=6.9 \mathrm{~Hz}, 2 \mathrm{H}) \mathrm{ppm} ;{ }^{13} \mathrm{C}$ $\operatorname{NMR}\left(100 \mathrm{MHz}, \mathrm{CDCl}_{3}\right): \delta 163.8,159.3,159.0,154.4,147.6,144.5,137.8,136.2,135.6,135.4$, $134.9,130.3,130.2,128.9,128.6,128.5,128.4,128.3,127.3,117.5,113.5,111.9,87.1,85.1,84.0$, $78.4,77.5,76.8,70.2,68.0,65.6,65.3,63.6,55.4,38.5,17.9$ ppm; IR (KBr): $v_{\max } 3476,3263$, 2934, 2837, 2263, 1732, 1654, 1610, 1560, 1504, 1415, 1394, 1326, 1283, 1249, 1195, 1098, 1059, $1026,981,829,741 \mathrm{~cm}^{-1}$; HRMS (ESI+) $m / z$ calcd for $\mathrm{C}_{50} \mathrm{H}_{48} \mathrm{~N}_{4} \mathrm{O}_{11} \mathrm{Na}[\mathrm{M}+\mathrm{Na}]^{+} 903.3212$; found 903.3210 .

Benzyl(1-((2R,4S,5R)-4-(((benzyloxy)carbonyl)oxy)-5-(hydroxymethyl)tetrahydrofuran2-yl)-5-((2-cyanoethoxy)methyl)-2-oxo-1,2-dihydropyrimidin-4-yl)carbamate (19): The solution of $18(500 \mathrm{mg}, 0.57 \mathrm{mmol})$ in $\mathrm{CH}_{2} \mathrm{Cl}_{2} / \mathrm{TFA}(v / v=50: 1,10 \mathrm{~mL})$ was stirred at $20{ }^{\circ} \mathrm{C}$ for $30 \mathrm{~min}$ and concentrated in vacuo. Flash column chromatography (PE/EA = 2:1) afforded 19 (297 mg, 90\%) as a white solid; $\mathrm{mp} 136-138{ }^{\circ} \mathrm{C} .{ }^{1} \mathrm{H}$ NMR $\left(400 \mathrm{MHz}, \mathrm{CDCl}_{3}\right): \delta 12.20$ (br, $1 \mathrm{H}), 8.10(\mathrm{~s}, 1 \mathrm{H}), 7.43-7.28(\mathrm{~m}, 10 \mathrm{H}), 6.36-6.31(\mathrm{~m}, 1 \mathrm{H}), 5.30(\mathrm{~d}, J=5.9 \mathrm{~Hz}, 1 \mathrm{H}), 5.18-5.16$ $(\mathrm{m}, 4 \mathrm{H}), 4.43(\mathrm{~s}, 2 \mathrm{H}), 4.24-4.22(\mathrm{~m}, 1 \mathrm{H}), 3.96(\mathrm{~d}, J=11.1 \mathrm{~Hz}, 1 \mathrm{H}), 3.87(\mathrm{~d}, J=11.5 \mathrm{~Hz}, 1 \mathrm{H})$, $3.75(\mathrm{t}, J=5.8 \mathrm{~Hz}, 2 \mathrm{H}), 2.98(\mathrm{~s}, 1 \mathrm{H}), 2.68(\mathrm{t}, J=5.8 \mathrm{~Hz}, 2 \mathrm{H}), 2.56-2.50(\mathrm{~m}, 1 \mathrm{H}), 2.42-2.33$ (m, 1H) ppm; $\left.{ }^{13} \mathrm{C} \mathrm{NMR} \mathrm{(100} \mathrm{MHz,} \mathrm{CDCl}_{3}\right): \delta 163.6,159.0,154.6,147.7,137.6,136.2,134.9$, $128.9,128.8,128.7,128.6,128.5,128.4,119.0,111.3,86.4,85.3,78.9,70.2,67.9,65.9,65.2,62.5$, 38.3, 19.3 ppm; IR (KBr): $v_{\max } 3265,2914,2266,1723,1650,1613,1565,1512,1415,1392$, $1326,1285,1194,1095,1056,983,740 \mathrm{~cm}^{-1}$; HRMS (ESI+) $m / z$ calcd for $\mathrm{C}_{29} \mathrm{H}_{30} \mathrm{~N}_{4} \mathrm{O}_{9} \mathrm{Na}$ $[\mathrm{M}+\mathrm{Na}]^{+}$601.1905; found 601.1910 .

Benzyl(1-((2R,4S,5R)-5-((((benzyloxy)(piperidin-1-yl)phosphoryl)oxy)methyl)-4(((benzyloxy)carbonyl)oxy)tetrahydrofuran-2-yl)-5-((2-cyanoethoxy)methyl)-2-oxo-1,2dihydropyrimidin-4-yl)carbamate (20): To a solution of 19 (250 mg, $0.44 \mathrm{mmol})$ and $\mathrm{Et}_{3} \mathrm{~N}(180 \mu \mathrm{L}, 1.3 \mathrm{mmol})$ in $\mathrm{CH}_{2} \mathrm{Cl}_{2}(10 \mathrm{~mL})$ was added the solution of 2-benzyl $N, N$ diisopropylchlorophosphoramidite $(205 \mathrm{mg}, 0.75 \mathrm{mmol})$ in $\mathrm{CH}_{2} \mathrm{Cl}_{2}(3 \mathrm{~mL})$. The reaction was stirred at $20^{\circ} \mathrm{C}$ for $30 \mathrm{~min}$ and concentrated in vacuo. The residue was concentrated and coevaporated with $\mathrm{CH}_{3} \mathrm{CN}(10 \mathrm{~mL} \times 2)$ and then dissolved in EtOAc $(5 \mathrm{~mL})$. The solution was filtered and concentrated in vacuo to afford the crude phosphoramidite. To a solution of the crude intermediate (ca. $0.44 \mathrm{mmol})$ in $\mathrm{CH}_{3} \mathrm{CN}(10 \mathrm{~mL})$ was added $1 \mathrm{H}-$ tetrazole $(61 \mathrm{mg}, 0.87 \mathrm{mmol})$ and deionized $\mathrm{H}_{2} \mathrm{O}(200 \mu \mathrm{L})$. The reaction was stirred at $20{ }^{\circ} \mathrm{C}$ for $5 \mathrm{~min}$ and then concentrated in vacuo. The residue was dissolved in $\mathrm{CH}_{2} \mathrm{Cl}_{2}$ $(20 \mathrm{~mL})$ and washed with aq. $\mathrm{HCl}$ solution $(0.02 \mathrm{M}, 20 \mathrm{~mL})$ and $\mathrm{H}_{2} \mathrm{O}(20 \mathrm{~mL})$. The organic layer was dried over anhydrous $\mathrm{Na}_{2} \mathrm{SO}_{4}$ and concentrated in vacuo to afford the crude $H$-phosphonate intermediate. To a solution of the crude $H$-phosphonate in $\mathrm{CH}_{3} \mathrm{CN}(10 \mathrm{~mL})$ were added piperidine $(52 \mu \mathrm{L}, 0.52 \mathrm{mmol}), \mathrm{Et}_{3} \mathrm{~N}(300 \mu \mathrm{L})$, and $\mathrm{CCl}_{4}(220 \mu \mathrm{L})$ at $0{ }^{\circ} \mathrm{C}$. The reaction was warmed to ambient temperature, stirred at $20^{\circ} \mathrm{C}$ for $30 \mathrm{~min}$, and concentrated in vacuo. The residue was dissolved in EtOAc $(5 \mathrm{~mL})$, filtered, and concentrated in vacuo. 
Flash column chromatography (PE/EA = 4:1) afforded $20(277 \mathrm{mg}, 79 \%)$ as a white solid, mp 44-45 ${ }^{\circ} \mathrm{C} .{ }^{1} \mathrm{H}$ NMR $\left(400 \mathrm{MHz}, \mathrm{CDCl}_{3}\right): \delta 12.20(\mathrm{br}, 1 \mathrm{H}), 7.86-7.84(\mathrm{~m}, 1 \mathrm{H}), 7.42-7.31(\mathrm{~m}$, $15 \mathrm{H}), 6.29-6.18(\mathrm{~m}, 1 \mathrm{H}), 5.25-5.20(\mathrm{~m}, 1 \mathrm{H}), 5.18-5.16(\mathrm{~m}, 4 \mathrm{H}), 5.06-4.93(\mathrm{~m}, 2 \mathrm{H}), 4.39-4.35$ $(\mathrm{m}, 1 \mathrm{H}), 4.34-4.31(\mathrm{~m}, 2 \mathrm{H}), 4.26-4.21(\mathrm{~m}, 2 \mathrm{H}), 3.72-3.65(\mathrm{~m}, 2 \mathrm{H}), 3.06-3.01(\mathrm{~m}, 4 \mathrm{H}), 2.63-2.57$ $(\mathrm{m}, 2 \mathrm{H}), 2.14-2.03(\mathrm{~m}, 1 \mathrm{H}), 1.97(\mathrm{~s}, 1 \mathrm{H}), 1.54-1.51(\mathrm{~m}, 2 \mathrm{H}), 1.48-1.41(\mathrm{~m}, 4 \mathrm{H}) \mathrm{ppm} ;{ }^{13} \mathrm{C}$ NMR $\left(100 \mathrm{MHz}, \mathrm{CDCl}_{3}\right): \delta$ 163.7, 159.4, 159.3, 154.3, 147.5, 147.4, 138.2, 137.9, 136.3, 136.2, $136.1,134.7,128.9,128.8,128.7,128.6,128.5,128.3,127.9,127.6,118.0,111.6,111.4,86.2,85.8$, 83.5, 78.1, 70.3, 68.2, 67.8, 65.6, 65.3, 45.4, 38.1, 26.1, 24.3, 18.7 ppm; ${ }^{31} \mathrm{P}$ NMR (162 MHz, $\left.\mathrm{CDCl}_{3}\right): \delta 8.77,8.45$ ppm; IR (KBr): $v_{\max } 3469,3260,2265,1662,1612,1561,1501,1452,1394$, $1327,1282,1195,1099,979,779,741 \mathrm{~cm}^{-1}$; HRMS (ESI+) $m / z$ calcd for $\mathrm{C}_{41} \mathrm{H}_{46} \mathrm{~N}_{5} \mathrm{O}_{11} \mathrm{PNa}$ $[\mathrm{M}+\mathrm{Na}]^{+}$838.2824; found 838.2820.

5-Hydroxymethyl-2'-deoxycytidine 5'-triphosphate, tetrasodium salt (14): Method A: To a solution of $17(67 \mathrm{mg}, 0.11 \mathrm{mmol})$ in DMF $(2 \mathrm{~mL})$ were added tris(tetra- $n$-butyl ammonium) hydrogen pyrophosphate (198 mg, $0.22 \mathrm{mmol})$ and DCI (78 mg, $0.66 \mathrm{mmol})$. The reaction was stirred at $20^{\circ} \mathrm{C}$ for $6 \mathrm{~h}$ and concentrated in vacuo. The residue was dissolved in $\mathrm{NH}_{3} \cdot \mathrm{H}_{2} \mathrm{O}(28 \mathrm{w} \%, 5 \mathrm{~mL})$, stirred at $40{ }^{\circ} \mathrm{C}$ for $12 \mathrm{~h}$, and concentrated in vacuo. The residue was dissolved in aq. NaOAc solution $(4 \mathrm{M}, 0.5 \mathrm{~mL})$ and then $\mathrm{EtOH}(10 \mathrm{~mL})$ was added. The precipitated crude product was collected by filtration, dissolved in deionized $\mathrm{H}_{2} \mathrm{O}(0.5 \mathrm{~mL})$, and loaded on a DEAE Sephadex A-25 ion exchange column $(1.6 \times 25 \mathrm{~cm})$. Elution with $\mathrm{NH}_{4} \mathrm{HCO}_{3}$ buffer (linear gradient 0.2 to $0.6 \mathrm{M}$ ), combination of appropriate fractions, and lyophilization afforded 1 in ammonium salt form. Passage of the solution of the ammonium salt in deionized $\mathrm{H}_{2} \mathrm{O}$ through a bed of Dowex 50W-X8 ion exchange resin $\left(\mathrm{Na}^{+}\right.$form) and lyophilization afforded $\mathbf{1}(46 \mathrm{mg}, 72 \%)$ as tetrasodium salt, a white solid. Method B: To a solution of $20(106 \mathrm{mg}, 0.13 \mathrm{mmol})$ and $\mathrm{Et}_{3} \mathrm{~N}(16 \mu \mathrm{L}, 0.13 \mathrm{mmol})$ in DMF $(3.3 \mathrm{~mL})$ was added $5 \mathrm{w} \% \mathrm{Pd} / \mathrm{C}(11 \mathrm{mg})$. The reaction was stirred at $20^{\circ} \mathrm{C}$ under $\mathrm{H}_{2}$ atmosphere for $3 \mathrm{~h}$. The catalyst was removed by a syringe filter $(0.45 \mu \mathrm{m}$ aperture $)$ under argon. To the DMF solution was added tris(tetra- $n$-butylammonium) hydrogen pyrophosphate $(242 \mathrm{mg}, 0.26 \mathrm{mmol})$ and DCI $(97 \mathrm{mg}, 0.82 \mathrm{mmol})$. The reaction was stirred at $20{ }^{\circ} \mathrm{C}$ for $6 \mathrm{~h}$ and concentrated in vacuo. The residue was dissolved in $\mathrm{NH}_{3} \cdot \mathrm{H}_{2} \mathrm{O}$ $(28 \mathrm{w} \%, 5 \mathrm{~mL})$ at $40^{\circ} \mathrm{C}$ for $12 \mathrm{~h}$ and concentrated in vacuo. The residue was further purified according to the procedures described in Method A to afford 14 (55 mg, 73\%) as tetrasodium salt, a white solid. ${ }^{1} \mathrm{H}$ NMR $\left(400 \mathrm{MHz}, \mathrm{D}_{2} \mathrm{O}\right): \delta 7.94(\mathrm{~s}, 1 \mathrm{H}), 6.24(\mathrm{t}, J=6.4 \mathrm{~Hz}, 1 \mathrm{H}), 4.58$ $(\mathrm{m}, 1 \mathrm{H}), 4.42(\mathrm{~s}, 2 \mathrm{H}), 4.17(\mathrm{~m}, 3 \mathrm{H}), 2.37-2.25(\mathrm{~m}, 2 \mathrm{H}) \mathrm{ppm} ;{ }^{13} \mathrm{C}$ NMR $\left(100 \mathrm{MHz}, \mathrm{D}_{2} \mathrm{O}\right): \delta$ 165.2, 157.4, 140.6, 107.1, 86.0, 85.7, 70.3, 65.1, 57.7, 39.5 ppm; ${ }^{31} \mathrm{P}$ NMR (162 MHz, D $\left.2 \mathrm{O}\right): \delta$ -7.90,-10.97, -22.05 ppm; IR: $v_{\max } 3346,2986,2856,1694,1413,1226,1080,924,813 \mathrm{~cm}^{-1}$; HRMS (ESI-): $m / z$ calcd for $\mathrm{C}_{10} \mathrm{H}_{18} \mathrm{~N}_{3} \mathrm{O}_{14} \mathrm{P}_{3}[\mathrm{M}-\mathrm{H}]^{-} 495.9711$; found 495.9710.

\section{Conclusions}

In summary, an improved method for practical synthesis of cyanoethtyl-protected 5 hmdC phosphoramidite has been developed. Direct synthesis of cyanoethyl-protected 5 hmdU via in situ alcoholysis and desilylation of 5BrmdU intermediate skipped the two limiting steps of the reported methods, i.e., the very low-yielding synthesis of 5hmdU and subsequent condensation with cyanoethanol under harsh conditions. In addition, the optimization of DMT and Bz protections along with application of the PyAOP-based $C^{4}$ amination method also significantly increased the synthetic efficiency. In a $5 \mathrm{~g}$ synthesis, the overall yield of $5 \mathrm{hmdC}$ phosphoramidite was promoted from reported $24 \%$ to $39 \%$. In addition, two practical routes for $5 \mathrm{hmdC}$ triphosphate synthesis on $50 \mathrm{mg}$ scale have also been developed on the basis of easily accessible cyanoethyl protected-5hmdU and 5hmdC intermediates. Moreover, mechanistic consideration of the remarkably improved reactivity of tritylating and activating reagents $\left(\mathrm{DMT}^{+} \mathrm{BF}_{4}{ }^{-}\right.$and PyAOP) suggests that utilizing ionizable reagents could be an effective strategy to significantly promote the reactions on sterically hindered substrates due to their more flattened conformations. 
Supplementary Materials: The following are available online, characterization data of $\mathbf{1}$ and $\mathbf{9 - 1 3}$ and Figures S1-S29: NMR spectra of all synthesized compounds.

Author Contributions: D.-Z.Y., Z.-Z.C., M.C. and Y.-Y.D. performed the experiments and analyzed the data; S.-Z.P. and Q.S. wrote the paper. All authors have read and agreed to the published version of the manuscript.

Funding: This research was funded by National Natural Science Foundation of China (No. 21961013).

Institutional Review Board Statement: Not applicable.

Informed Consent Statement: Not applicable.

Data Availability Statement: The data presented in this study are available in Supplementary Materials.

Conflicts of Interest: The authors declare no conflict of interest.

\section{References}

1. Kriaucionis, S.; Heintz, N. The nuclear DNA base 5-hydroxymethylcytosine is present in purkinje neurons and the brain. Science 2009, 324, 929-930. [CrossRef] [PubMed]

2. Tahiliani, M.; Koh, K.P.; Shen, Y.-H.; Pastor, W.A.; Bandukwala, H.; Brudno, Y.; Agarwal, S.; Iyer, L.M.; Liu, D.R.; Aravind, L.; et al. Conversion of 5-methylcytosine to 5-hydroxymethylcytosine in mammalian DNA by MLL partner TET1. Science 2009, 324, 930-935. [CrossRef] [PubMed]

3. $\mathrm{Wu}, \mathrm{X} . J . ;$ Zhang, Y. TET-mediated active DNA demethylation: Mechanism, function and beyond. Nat. Rev. Genet. 2017, 18, 517-534. [CrossRef]

4. Munzel, M.; Globisch, D.; Carell, T. 5-Hydroxymethylcytosine, the sixth base of the genome. Angew. Chem. Int. Ed. 2011, 50, 6460-6468. [CrossRef] [PubMed]

5. $\mathrm{Wu}, \mathrm{H} . ;$ Zhang, Y. Reversing DNA methylation: Mechanisms, genomics, and biological functions. Cell 2014, 156, 45-68. [CrossRef] [PubMed]

6. He, Y.-F.; Li, B.-Z.; Li, Z.; Liu, P.; Wang, T.; Tang, Q.-Y.; Ding, J.; Jia, Y.; Chen, Z.; Li, L.; et al. Tet-mediated formation of 5-carboxylcytosine and its excision by TDG in mammalian DNA. Science 2011, 333, 1303-1307. [CrossRef] [PubMed]

7. Spada, F.; Schiffers, S.; Kirchner, A.; Zhang, Y.; Arista, G.; Kosmatchev, O.; Korytiakova, E.; Rahimoff, R.; Ebert, C.; Carell, T. Active turnover of genomic methylcytosine in pluripotent cells. Nat. Chem. Biol. 2020, 16, 1411-1419. [CrossRef] [PubMed]

8. Stroud, H.; Feng, S.; Kinney, S.M.; Pradhan, S.; Jacobsen, S.E. 5-Hydroxymethylcytosine is associated with enhancers and gene bodies in human embryonic stem cells. Genome Biol. 2011, 12, R54. [CrossRef] [PubMed]

9. Munzel, M.; Globisch, D.; Bruckl, T.; Wagner, M.; Welzmiller, V.; Michalakis, S.; Muller, M.; Biel, M.; Carell, T. Quantification of the sixth DNA base hydroxymethylcytosine in the brain. Angew. Chem. Int. Ed. 2010, 49, 5375-5377. [CrossRef] [PubMed]

10. Stricker, S.H.; Götz, M. DNA-methylation: Master or slave of neural fate decisions? Front. Neurosci. 2018, 12, 5. [CrossRef] [PubMed]

11. Xiong, J.; Jiang, H.-P.; Peng, C.-Y.; Deng, Q.-Y.; Lan, M.-D.; Zeng, H.; Zheng, F.; Feng, Y.-Q.; Yuan, B.-F. DNA hydroxymethylation age of human blood determined by capillary hydrophilic-interaction liquid chromatography/mass spectrometry. Clin. Epigenet. 2015, 7, 72. [CrossRef] [PubMed]

12. Ito, S.; D'Alessio, A.C.; Taranova, O.V.; Hong, K.; Sowers, L.C.; Zhang, Y. Role of Tet proteins in 5mC to 5hmC conversion, ES-cell self-renewal and inner cell mass specification. Nature 2010, 466, 1129-1133. [CrossRef] [PubMed]

13. Scourzic, L.; Mouly, E.; Bernard, O.A. TET proteins and the control of cytosine demethylation in cancer. Genome Med. 2015, 7, 9. [CrossRef] [PubMed]

14. Chen, M.-L.; Shen, F.; Huang, W.; Qi, J.-H.; Wang, Y.; Feng, Y.-Q.; Liu, S.-M.; Yuan, B.-F. Quantification of 5-methylcytosine and 5-hydroxymethyl cytosine in genomic DNA from hepatocellular carcinoma tissues by capillary hydrophilic-interaction liquid chromatography/quadrupole TOF mass spectrometry. Clin. Chem. 2013, 59, 824-832. [CrossRef] [PubMed]

15. Olinski, R.; Starczak, M.; Gackowski, D. Enigmatic 5-hydroxymethyluracil: Oxidatively modified base, epigenetic mark or both? Mutat. Res. Rev. Mutat. Res. 2016, 767, 59-66. [CrossRef] [PubMed]

16. Shi, D.-Q.; Ali, I.; Tang, J.; Yang, W.-C. New insights into 5hmC DNA modification: Generation, distribution and function. Front. Genet. 2017, 8, 100. [CrossRef]

17. Pfaffeneder, T.; Sadeghian, K.; Hackner, B.; Steigenberger, B.; Schröder, A.S.; Steinbacher, J.; Kashiwazaki, G.; Höfner, G.; Wanner, K.T.; Ochsenfeld, C.; et al. Deamination, oxidation, and C-C bond cleavage reactivity of 5-hydroxymethylcytosine, 5-formylcytosine, and 5-carboxycytosine. J. Am. Chem. Soc. 2013, 135, 14593-14599.

18. Schröder, A.S.; Raddaoui, N.; Carell, T. Synthesis of $(R)$-configured 2 '-fluorinated $\mathrm{mC}, \mathrm{hmC}, \mathrm{fC}$, and caC phosphoramidites and oligonucleotides. Org. Lett. 2016, 18, 4368-4371. [CrossRef]

19. Steigenberger, B.; Schiesser, S.; Hackner, H.; Brandmayr, C.; Laube, S.K.; Steinbacher, J.; Pfaffeneder, T.; Carell, T. Synthesis of 5-hydroxymethyl-, 5-formyl-, and 5-carboxycytidine triphosphates and their incorporation into oligonucleotides by polymerase chain reaction. Org. Lett. 2013, 15, 366-369. [CrossRef] 
20. Vaníková, Z.; Janoušková, M.; Kambová, M.; Krásný, L.; Hocek, M. Switching transcription with bacterial RNA polymerase through photocaging, photorelease and phosphorylation reactions in the major groove of DNA. Chem. Sci. 2019, 10, 3937-3942. [CrossRef]

21. Tardy-Planechaud, S.; Fujimoto, J.; Lin, S.S.; Sowers, L.C. Solid phase synthesis and restriction endonuclease cleavage of oligodeoxynucleotides containing 5-(hydroxymethyl)-cytosine. Nucleic Acids Res. 1997, 25, 553-558. [CrossRef] [PubMed]

22. de Kort, M.; de Visser, P.C.; Kurzeck, J.; Meeuwenoord, N.J.; van der Marel, G.A.; Rüger, W.; van Boom, J.H. Chemical and enzymatic synthesis of DNA fragments containing 5-( $\beta$-D-glucopyranosyloxymethyl)- 2 -deoxycytidine-a modified nucleoside in T4 phage DNA. Eur. J. Org. Chem. 2001, 11, 2075-2082. [CrossRef]

23. Münzel, M.; Globisch, D.; Trindler, C.; Carell, T. Efficient synthesis of 5-hydroxymethylcytosine containing DNA. Org. Lett. 2010, 12, 5671-5673. [CrossRef] [PubMed]

24. Dai, Q.; Song, C.-X.; Pan, T.; He, C. Syntheses of two 5-hydroxymethyl-2'-deoxycytidine phosphoramidites with TBDMS as the 5-hydroxymethyl protecting group and their incorporation into DNA. J. Org. Chem. 2011, 76, 4182-4188. [CrossRef] [PubMed]

25. Chakrapani, A.; Hausnerová, V.V.; Ruiz-Larrabeiti, O.; Pohl, R.; Krásný, L.; Hocek, M. Photocaged 5-(hydroxymethyl)pyrimidine nucleoside phosphoramidites for specific photoactivatable epigenetic labeling of DNA. Org. Lett. 2020, 22, 9081-9085. [CrossRef] [PubMed]

26. Hansen, A.S.; Thalhammer, A.; El-Sagheer, A.H.; Brown, T.; Schofield, C.J. Improved synthesis of 5-hydroxymethyl-2'-deoxycytidine phosphoramidite using a 2'-deoxyuridine to 2'-deoxycytidine conversion without temporary protecting groups. Bioorg. Med. Chem. Lett. 2011, 21, 1181-1184. [CrossRef]

27. Xuan, S.; Wu, Q.; Cui, L.; Zhang, D.; Shao, F. 5-Hydroxymethylcytosine and 5-formylcytosine containing deoxyoligonucleotides: Facile syntheses and melting temperature studies. Bioorg. Med. Chem. Lett. 2015, 25, 1186-1191. [CrossRef]

28. Shahsavari, S.; Chen, J.; Wigstrom, T.; Gooding, J.; Gauronskas, A.; Fang, S. Tritylation of alcohols under mild conditions without using silver salts. Tetrahedron Lett. 2016, 57, 3877-3880. [CrossRef]

29. Akula, H.K.; Kokatla, H.; Andrei, G.; Snoeck, R.; Schols, D.; Balzarini, J.; Yang, L.-J.; Lakshman, M.K. Facile functionalization at the $\mathrm{C}^{4}$ position of pyrimidine nucleosides via amide group activation with (benzotriazol-1-yloxy)tris(dimethylamino)phos- phonium hexafluorophosphate (BOP) and biological evaluations of the products. Org. Biomol. Chem. 2017, 15, 1130-1139. [CrossRef]

30. Zheng, X.-A.; Huang, H.-S.; Kong, R.; Chen, W.-J.; Gong, S.-S.; Sun, Q. An efficient PyAOP-based C $C^{4}$-amination method for direct access of oxidized $5^{\mathrm{Me}} \mathrm{dC}$ derivatives. Tetrahedron 2018, 74, 7095-7101. [CrossRef]

31. Sun, Q.; Sun, J.; Gong, S.-S.; Wang, C.-J.; Pu, S.-Z.; Feng, F.-D. Efficient synthesis of 5-hydroxymethyl-, 5-formyl-, and 5-carboxyl2'-deoxycytidine and their triphosphates. RSC Adv. 2014, 4, 36036-36039. [CrossRef]

32. Sun, Q.; Gong, S.; Sun, J.; Wang, C.; Liu, S.; Liu, G.; Ma, C. Efficient synthesis of nucleoside $5^{\prime}$-triphosphates and their $\beta, \gamma$-bridging oxygen-modified analogs from nucleoside 5'-phosphates. Tetrahedron Lett. 2014, 55, 2114-2118. [CrossRef]

33. Sun, Q.; Gong, S.; Sun, J.; Liu, S.; Xiao, Q.; Pu, S. A P(V)-N activation strategy for the synthesis of nucleoside polyphophates. J. Org. Chem. 2013, 78, 8417-8426. [CrossRef] [PubMed] 